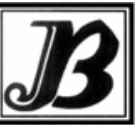

J. bio-sci. 18: 49-52, 2010

ISSN 1023-8654

http://www.banglajol.info/index.php/JBS/index

\title{
INFLUENCE OF JUVENILE HORMONE ANALOGUE AND INSULIN APPLIED AT THIRD AND FOURTH INSTAR ON SOME LARVAL AND COCOON CHARACTERS IN BOMBYX MORI L.
}

\author{
S G Mali, V B Khyade* \\ Shardabai Pawar College of Education for Women, Shardanagar, Baramati, Pune 413115, India
}

\begin{abstract}
Context: Juvenile hormone and insulin prolongs the larval duration in mulberry silkworm thereby extending the feeding period which results in an increase in cocoon weight and cocoon shell weight. The larval treatment with Juvenile Hormone analogue could be utilized to increase silk production.

Objective: The objectives of the study is to find out the influence of a Juvenile Hormone analogue, Manta and human insulin to the larval instars of silkworm, Bombyx mori (L) $\left(\mathrm{PM} \times \mathrm{CSR}_{2}\right)$ on larval growth, development and cocoon characters. Materials and Methods: The disease free layings of polyvoltine race (PM $\times \mathrm{CSR}_{2}$ ) of silkworm, B. mori were used for
the study. The acetone solution of manta was used for topical application to third and fourth instar larvae at 36 hours
after second and third moult at the rate of $8 \mathrm{ml}$ solution application to the group of 100 larvae through hand sprayer.
For insulin treatment $100 \mathrm{~g}$ fresh mulberry leaves were soaked in $300 \mathrm{ml}$ of aqueous solution of insulin for half an
hour. The first feeding after treating the larvae with manta consisted of insulin treated leaves. The pre-cocooning
parameters such as larval duration, larval weight, silkgland weight and the post cocooning parameters such as
female and male cocoon weights and their shell weights and shell ratio were calculated.
\end{abstract}

Results: The results indicate the larval duration and larval and silkgland weight significantly increased after treatment with manta or manta followed by insulin treatments. The results of the present study suggest that the treatment with manta followed by insulin yields heavier cocoons and cocoon shells in both the sexes than those obtained after treatment with manta or insulin.

Conclusion: It can be suggested that the treatment with Manta followed by insulin may be utilized to increase silk production by increasing the heavier larva, cocoon, shell.

Keywords: Bombyx mori, silkworm, Juvenile hormone, Manta, insulin.

\section{Introduction}

It was first reported by Akai and Kobayashi (1971) that the administration of juvenile hormone (JH) prolongs the larval duration and results in a significant increase in cocoon weight and cocoon shell weight in Bombyx mori (L). Since several investigators have shown that the treatment with $\mathrm{JH}$-analogues including Manta increased the larval duration (Akai et al. 1973, Kobari and Akai 1978, Shigematsu 1978, Kamada et al. 1979, Shibukawa and Akai 1981, Washida 1984) larval weight (Shigematsu et al. 1979, Krishnaswamy et al. 1981), Silkgland weight and its proteins, amino acids and nucleic acid content (Shigematsu 1978, Shigematsu et al. 1978, 1979, Wu et al. 1978, Chen et al. 1982), cocoon weight and cocoon shell weight (Amori et al. 1977, Kobasri and Akai 1978, 1979, Kamada et al. 1979, Krishnaswamy et al. 1981, Akai et al. 1985) and egg productivity (Kimura et al. 1986) in different races of Japanese silkworms. Occurrence of insulin like peptides has been reported and it is suggested that the vertebrate insulin may stimulate growth, lipid mobilization, sugar uptake and cellular internalization in insects and other invertebrates (Kramer 1983). Recent studies have shown that the treatment with insulin improves the pre-cocooning and some of the post cocooning parameters of the silkworm (Magdum and Hooli 1989). These reports suggest that the economic parameters of the silkworm are improved after treatment with $\mathrm{JH}$-analogues or insulin.

* Corresponding author E-mail: vitthalrao.khyade@gmail.com 
However, there are no reports on the effect of $\mathrm{JH}$-analogues when applied in combination with insulin or other hormones on the economic parameters of silkworms. Therefore in the present study was undertaken to find out the effect of repeated applications with Manta followed by insulin on the economic parameters of the polyvoltine breed of $B$. mori.

\section{Materials and Methods}

The disease free layings of polyvoltine race $\left(\mathrm{PM} \times \mathrm{CSR}_{2}\right)$ of silkworm, $B$. mori were procured through Agriculture Development Trust, Baramati, Pune, India. They were processed for incubation (black boxing), brushing and rearing as per standard method of silkworm rearing (Krishnaswamy 1978). After second moult, the larvae of third instar were divided into five groups, each with 100 larvae. The manta and insulin were procured through Himalaya Drug Company, Bangalore.

Manta stock solution was prepared $(4 \mu \mathrm{g} / \mathrm{ml})$ with acetone. Aqueous solution of insulin $(4 \mathrm{IU} / \mathrm{ml})$ was also prepared. The acetone solution of manta was used for topical application to third and fourth instar larvae at 36 hours after second and third moult at the rate of $8 \mathrm{ml}$ solution application to the group of 100 larvae through hand sprayer. For insulin treatment $100 \mathrm{~g}$ fresh mulberry leaves were soaked in $300 \mathrm{ml}$ of aqueous solution of insulin for half an hour. The first feeding after treating the larvae with manta consisted of insulin treated leaves (100 $\mathrm{g}$ for the group of 100 larvae).

Thus the first group of larvae received only two topical applications manta and two insulin treated feedings. The second group of larvae received only two topical applications manta. Third group of larvae received two feedings of insulin treated mulberry leaves. The fourth and fifth groups of larvae served solvent treated and untreated control groups respectively. Other feedings and rearing schedule was as usual.

The record of daily larval weight was maintained. For silkglands, ten larvae from each group of fifth instar were selected at random on fifth day. They were anaesthetized with chloroform soaked cotton pad; dissected in insect ringer; both the salivary glands from individual larvae were separated, taken outside and weighed accurately. Larval weight and weight of silk glands were used for estimation of tissue somatic index. Remaining larvae of each group were processed for further rearing, moulting mature larvae for spinning and harvesting the cocoons. The pre cocooning parameters such as larval duration, larval weight, silkgland weight and the post cocooning parameters such as female and male cocoon weights and their shell weights and shell ratio were calculated. Each mean value is the average reading from ten worms, two from each replication. The larval duration and larval weight was taken at the end of the last larval instar. The silkgland weight was taken just before the commencement of spinning activity at the end of the last larval instar.

The data collected were subjected to one way analysis of variance test to find out of the significance between the corresponding parameters of the treated groups and the untreated controls. The percent value for cocooning percentage, moth emergence percentages and female and male cocoon shell ratio was transformed into sine angular values for statistical analysis. The percent index value was calculated for each parameter of experimental groups over the corresponding parameters on untreated controls.

\section{Results}

Larval duration, larval weight, silkgland weight, tissue somatic index and cocoon characters of $B$. mori L. in treated and control groups are presented in Tables 1 and 2 . The results indicate the larval duration and larval weight significantly increased after treatment with manta or manta followed by insulin treatments. The treatment with insulin has increased the larval duration non significant but increased the larval weight significantly which is suggested to be due to the growth stimulating effect of insulin of the larvae. The silkglands weight significantly increased with treatment of manta followed by insulin and also after treatment with manta or insulin. Tissue somatic index also shows the similar results (Table 1). 
The female cocoon weights and their shell weights also increased significantly after treatment with manta followed by insulin and also after treatment with insulin except for the male cocoon weight treatment within insulin. The results of the present study suggest that the treatment with manta followed by insulin yields heavier cocoons and cocoon shells in both the sexes than those obtained after treatment with manta or insulin (Table 2). There was no significant difference in the parameters of the distilled water treated control when compared with the corresponding parameters of the untreated control.

Table 1. Larval duration, larval weight, silkgland weight and tissue somatic index of Bombyx mori L. in treated and control groups.

\begin{tabular}{|c|c|c|c|c|}
\hline Treatment & $\begin{array}{c}\text { Larval duration (h) } \\
3^{\text {rd }} \text { through } 5^{\text {th }} \text { instar } \\
\text { Mean } \pm \text { S.D } \\
\text { (Percent index) } \\
\end{array}$ & $\begin{array}{l}\text { Mature larval weight }(\mathrm{g}) \\
\text { Mean } \pm \text { S.D } \\
\text { (Percent index) }\end{array}$ & $\begin{array}{l}\text { Silkgland weight (g) } \\
\text { Mean } \pm \text { S.D } \\
\text { (Percent index) }\end{array}$ & $\begin{array}{c}\text { Tissue somatic } \\
\text { index } \\
\text { Mean } \pm \text { S.D } \\
\text { (Percent index) }\end{array}$ \\
\hline Mantha & $\begin{array}{c}412.54 \pm 19.68^{\star} \\
(7.23)\end{array}$ & $\begin{array}{c}2.38 \pm 0.23^{\star *} \\
\quad(34.46)\end{array}$ & $\begin{array}{l}0.619 * \star * \\
(51.34)\end{array}$ & $\begin{array}{c}26.03^{\star \star \star} \\
(12.59)\end{array}$ \\
\hline Insulin & $\begin{array}{c}390.63 \pm 17.75 \\
(1.536)\end{array}$ & $\begin{array}{c}2.39 \pm 0.21^{*} \\
(35.02)\end{array}$ & $\begin{array}{l}0.587^{* *} \\
(43.52)\end{array}$ & $\begin{array}{c}24.55^{\star *} \\
(6.19)\end{array}$ \\
\hline Mantha + Insulin & $\begin{array}{c}397.76 \pm 21.47^{*} \\
(3.39)\end{array}$ & $\begin{array}{c}2.42 \pm 0.17 \text { ** } \\
\quad(36.72)\end{array}$ & $\begin{array}{l}0.657^{\text {** }} \\
(60.63)\end{array}$ & $\begin{array}{l}27.17^{\star *} \\
(17.52)\end{array}$ \\
\hline Solvent Treated control & $\begin{array}{c}384.72 \pm 18.31 \\
(0)\end{array}$ & $\begin{array}{c}1.78 \pm 0.29 \\
(0.564)\end{array}$ & $\begin{array}{l}0.413 \\
(9.77)\end{array}$ & $\begin{array}{c}23.12 \\
(0)\end{array}$ \\
\hline Untreated Control & $384.72 \pm 18.31$ & $1.77 \pm 0.29$ & 0.409 & 23.12 \\
\hline
\end{tabular}

Table 2. Cocoon weight, shell weight and silk ratio of Bombyx mori L. in treated and control groups.

\begin{tabular}{|c|c|c|c|c|c|c|}
\hline \multirow[b]{2}{*}{ Treatment } & \multicolumn{3}{|c|}{ Female } & \multicolumn{3}{|c|}{ Male } \\
\hline & $\begin{array}{c}\text { Cocoon } \\
\text { Weight }(\mathrm{g}) \\
\text { Mean } \pm \text { S.D } \\
\text { (Percent index) }\end{array}$ & $\begin{array}{l}\text { Shell Weight }(\mathrm{g}) \\
\text { Mean } \pm \text { S.D } \\
\text { (Percent index) }\end{array}$ & $\begin{array}{c}\text { Shell Ratio } \\
\text { Mean } \\
\text { (Percent index) }\end{array}$ & $\begin{array}{c}\text { Cocoon } \\
\text { Weight }(\mathrm{g}) \\
\text { Mean } \pm \text { S.D } \\
\text { (Percent index) }\end{array}$ & $\begin{array}{l}\text { Shell Weight }(\mathrm{g}) \\
\text { Mean } \pm \text { S.D } \\
\text { (Percent index) }\end{array}$ & $\begin{array}{c}\text { Shell Ratio } \\
\text { Mean } \\
\text { (Percent index) }\end{array}$ \\
\hline Manta & $\begin{array}{c}1.105 \pm 0.164^{*} \\
(6.56)\end{array}$ & $\begin{array}{c}0.139 \pm 0.003^{*} \\
(13.00)\end{array}$ & $\begin{array}{l}12.58 \\
(6.07)\end{array}$ & $\begin{array}{c}0.831 \pm 0.184 \\
(0.972)\end{array}$ & $\begin{array}{c}0.122 \pm 0.006 \\
(7.964)\end{array}$ & $\begin{array}{c}14.681 \\
(6.92)\end{array}$ \\
\hline Insulin & $\begin{array}{c}1.161 \pm 0.174^{*} \\
(11.96)\end{array}$ & $\begin{array}{c}0.147 \pm 0.008^{*} \\
(19.51)\end{array}$ & $\begin{array}{l}12.66 \\
(6.74)\end{array}$ & $\begin{array}{c}0.845 \pm 0.171 \\
(2.673)\end{array}$ & $\begin{array}{c}0.126 \pm 0.0076 \\
(11.504)\end{array}$ & $\begin{array}{c}14.911 \\
(8.59)\end{array}$ \\
\hline Manta + Insulin & $\begin{array}{c}1.293 \pm 0.169^{* * *} \\
(24.68)\end{array}$ & $\begin{array}{c}0.168 \pm 0.008)^{\star \star \star} \\
(36.58)\end{array}$ & $\begin{array}{l}12.99 \\
(9.53)\end{array}$ & $\begin{array}{c}0.994 \pm 0.154^{\star *} \\
(20.77)\end{array}$ & $\begin{array}{c}0.153 \pm 0.0072 \\
(35.39)\end{array}$ & $\begin{array}{l}15.392^{*} \\
(12.10)\end{array}$ \\
\hline $\begin{array}{l}\text { Solvent Treated } \\
\text { control }\end{array}$ & $\begin{array}{c}1.021 \pm 0.378 \\
(-1.542)\end{array}$ & $\begin{array}{c}0.122 \pm 0.008 \\
(-0.813)\end{array}$ & $\begin{array}{l}11.95 \\
(0.75)\end{array}$ & $\begin{array}{c}0.831 \pm 0.123 \\
(-0.813)\end{array}$ & $\begin{array}{c}0.115 \pm 0.006 \\
(1.77)\end{array}$ & $\begin{array}{l}13.838 \\
(0.779)\end{array}$ \\
\hline $\begin{array}{l}\text { Untreated } \\
\text { Control }\end{array}$ & $1.037 \pm 0.339$ & $0.123 \pm 0.008$ & 11.86 & $0.823 \pm 0.129$ & $0.113 \pm 0.0049$ & 13.731 \\
\hline
\end{tabular}

\section{Discussion}

The treatment with manta has been reported to increase the larval duration thereby extending the feeding period which results in increased larval weight (Kobari and Akai 1978, Washida 1984, Magdum and Hooli 1989). Similar results are reported after treatment with $\mathrm{JH}$ or JH-analogues in Japanese races of silkworms (Akai and Kobayashi 1971, Akai et al. 1973, Shigematsu 1978, Shigematsu et al. 1979). The increase in silkgland weight after treatment with manta or manta followed by insulin might be due to increased synthetic activity of the silkglands, since the treatment with $\mathrm{JH}$ or $\mathrm{JH}$-analogue reported to increase the silk protein synthesis, replication of DNA and accumulation of RNA in silkgland (Akai et al. 1971, Amori et al. 1977, Chen et al. 1982). The increase in silkgland weight after treatment with insulin might be due to the stimulatory effect of insulin on the synthetic activity of silkgland as suggested by Kramer (1983). 


\section{Conclusion}

From the present study, it is evident that there is 35.99 percent increase in cocoon shell weight (average of both sexes) after treatment with manta followed by insulin. Hence it is suggested that the treatment with Manta followed by insulin may be utilized to increase silk production.

\section{References}

Akai H, Kobayashi M. 1971. Induction of prolonged larval instar by juvenile hormone in Bombyx mori (L). (Lepidoptera: Bombycidae). Appl Entmol Zool 6,138-139.

Akai H, Kiguchi K, Mori K. 1973. The influence of juvenile hormone on the growth and metamorphosis of Bombyx mori larvae. Bull Seric Expt Stat 25, 287-305.

Akai H, Kimura K, Kiuchi M, Shibukawa A. 1985. Increase of production by repeated treatment with a juvenile hormone analogue. J Seric Sci Jpn 54, 297-299.

Amori S, Ozawa Y, Nishimura M. 1977. Timely administration of synthetic compounds with the juvenile hormone activity to silkworm larvae reared on an artificial diet. J Seric Sci Jpn 46, 69-76.

Chen Y, Feng H, Guo F. 1982. Effects of Juvenile hormone analogue on the protein content and development of silkgland in the $5^{\text {th }}$ instar silkworm, Insect knowledge 19, 25-28.

Kamada A, Shimada S, Asano S. 1979. Studies of utilization of methoprene, a synthetic compound with juvenile hormone activity for silkworm rearing: I Effect on the development of fifth instar larvae. J Seric Sci Jpn 48, 129-136.

Kimura K, Kiuchi M, Akai H. 1986. Effect of JH analogue and anti JH treatments on the number and size of the silkworm eggs. J Seric Sci Jpn 47, 335-337.

Kobari Y, Akai H. 1978. Utilization of Manta (Synthetic compound of juvenile hormone activity) for the silkworm rearing. J Seric Sci Jpn 47, 315-319.

Kobari Y, Akai H. 1979. On quantitative increase of silk production by the administration of juvenile hormone (Manta). J Seric Sci Jpn 48, 37-42.

Kramer KJ. 1983. Vertebrate hormones in insects. In Kirkut GA, Gilbert LI (eds) Comparitive Insect Physiology, Biochemistry and Pharmacology. Pergamon Press., London New York. Vol. VII. Pp. 511-535.

Krishnaswany S. 1978. Improved method of rearing young age (Chawki) silkworms. Bulletin No. 3 CSRTI, Mysore, 1-27.

Krishnaswamy S, Benchamin KV, Raghuraman R, Geetadevi RG. 1981. Studies on the effect of Juvenile hormone analogue ZR512 in silkworm, Bombyx mori L. to improve silk yield. Proc. Symp and seminar on sericulture, TN Agri Univ Coimbtore, 124-129.

Magdum SB, Hooli MA. 1989. Effect of insulin on the polyvoltine silkworm, the pure Mysore breed of Bombyx mori L. Sericologia 29(1),17-27.

Shibukawa A, Akai H. 1981. Effect of Manta on the silk production of a silkworm race producting heavy cocoon shells. J Seric Sci Jpn 50, 73-76.

Shigematsu H. 1978. The nature of juvenoid effects on growth and changes of protein, aminoacid and nuclic acid content in silkworm, Bombyx mori - on the case of application of excessive dose. J Seric Sci Jpn 47, 292-300.

Shigematsu H, Kurata E, Takeshila H. 1978. Nuclic acid accumulation of silkgland of Bombyx Mori in relation to silk protein. Comp Biochem Physiol B 61, 237-242. http://dx.doi:10.1016/0305-0491(78)90168-2

Shigematsu H, Kamada A, Asano S. 1979. Studies on the utilization of methoprene, a synthetic compound with juvenile hormone activity, for the silkworm rearing: II An aspect of silk formation in the silkworm, Bombyx mori applied with methoprene examine by vital staining with thionin. J Seric Sci Jpn 48, 282-286.

Washida S. 1984. Influence of juvenile hormone analogues applied at fourth instar on larval growth and cocoon weight in Bombyx mori. J Seric Sci Jpn 53, 210-215.

Wu TN, Hu CY, Quo F. 1978. Effect of juvenile hormone analogue on the nuclic acid metabolism on the posterior silkgland in silkworm, Bombyx mori L. Acta Entomologia Sinica 21, 290-296. 